\section{RDD Revista Produção e Desenvolvimento}

Research in Production and Development
eISSN: 2446-9580

Doi: https://doi.org/10.32358/rpd.2021.v7.531

\title{
THERMAL DEGRADATION OF AÇAÍ SEEDS AND POTENTIAL APPLICATION IN THERMOCHEMICAL PROCESSES
}

Luciano dos Santos Oliveira (https://orcid.org/0000-0001-9251-3601)1 , luciano.so11@outlook.com Arthur Vinicius Sousa Silva (https://orcid.org/0000-0003-3259-8927)2, arthsilva6@gmail.com Charles Correa Conconi (https://orcid.org/0000-0002-2583-7750) ${ }^{3}$, charles.conconi@gmail.com Edelvio de Barros Gomes (https://orcid.org/0000-0003-4983-6282) Waldir Antônio Bizzo (https://orcid.org/0000-0003-1505-4266) $)^{5}$, bizzo@ fem.unicamp.br Glauber Cruz (https://orcid.org/0000-0003-0468-553X)1, cruz.glauber@ufma.br

1. Department of Mechanical Engineering, Federal University of Maranhão, 65080-805, São Luís-MA, Brazil

2. Department of Mechanics and Materials, Federal Institute of Maranhão, 65030-005, São Luís-MA, Brazil

3. Materials Research Environmental Lab, Mercedes-Benz Brazil, 09680-900, São Bernardo do Campo-SP, Brazil

4. Department of Health Technology and Biology, Federal Institute of Bahia, 40110-150, Salvador-BA, Brazil

5. Department of Mechanical Engineering, University of Campinas, 13083-970, Campinas-SP, Brazil

Submitted: 26/04/2021. Accepted: 25/05/2021

Published: 07/06/2021

\begin{abstract}
Purpose: Thermal and Physicochemical evaluation of açaí seeds for its use in thermochemical conversion processes for clean energy generation.

Methodology: Experimental and qualitative research, using analyzes such as: Thermal analysis (TG/DTG and DTA curves) and Calorimetry, Ultimate and Proximate analyzes, Scanning Electron Microscopy, Energy Dispersive Spectroscopy, X-Ray Diffraction, Fourier Transform Infrared Spectroscopy and Optical Emission Spectroscopy - Inductively Coupled Plasma.

Findings: It was noted that the açaí seeds presented carbon, hydrogen, and oxygen contents as majority elements and a Higher Heating Value (HHV) of $19.8 \mathrm{MJ} \mathrm{kg}^{-1}$. Nitrogen and lead elements were found as trace elements. However, highly polluting elements, e.g., sulfur, cadmium and arsenic were not detected in the samples.

Originality: The utilization of açaí seeds by means of thermoconversion processes for bioenergetic purposes can be an attractive socioenvironmental, reducing disposal in inappropriate places, adding considerable value to waste and still protecting the environment.
\end{abstract}

Keywords: açaí seeds, added value, bioenergy, biomass characterization, thermal analysis.

\section{DEGRADAÇÃo TÉRMICA DE CAROÇOS DE AÇAÍ E POTENCIAL APLICAÇÃo EM PROCESSOS TERMOQUÍMICOS}

\section{RESUMO}

Objetivo: Caracterização térmica e físico-química dos caroços de açaí para utilização dessa biomassa em processos de conversão termoquímica para geração de energia limpa.

Metodologia: Pesquisa experimental de cunho qualitativo, na qual foram utilizadas diferentes análises como: Análise Termogravimétrica/Derivada da Termogravimetria, Análise Térmica Diferencial e Calorimétrica, Análises Elementar e Imediata, Microscopia Eletrônica de Varredura, Espectroscopia de Energia Dispersiva, Difração de Raios-X, Infravermelho por Transformada de Fourier, Espectroscopia de Emissão Ótica por Plasma Acoplado Indutivamente.

Resultados: Verificou-se que os caroços de açaí apresentaram teores de carbono, hidrogênio e oxigênio como elementos majoritários e um Poder Calorífico Superior (PCS) da ordem de 19,8 MJ kg-1. Os elementos nitrogênio e chumbo foram encontrados em quantidades inferiores e considerados como elementos traços. Elementos altamente poluentes como enxofre, cádmio e arsênio não foram detectados nas amostras de caroços de açaí.

Originalidade: $\mathrm{O}$ emprego dos caroços de açaí por meio do reaproveitamento térmico para fins bioenergéticos pode ser atrativo do ponto de vista socioambiental, reduzindo o descarte em locais inapropriados, agregando um valor considerável a esses resíduos e sobretudo protegendo o meio ambiente.

Palavras-chave: caroços de açaí, valor agregado, bioenergia, caracterização de biomassa, análise térmica. 


\section{INTRODUCTION}

The increase in worldwide energy demand is becoming more expressive and, in this current context, for maintaining a structure of goods and services, the oil is still indispensable due to its high energy value (Domingos et al., 2012). However, limited oil reserves as a non-renewable resource and unstable prices, in addition to the high gaseous emissions harmful to the environment intensified the concerns about the greenhouse effect, reflecting the need to seek new alternative sources for the energy generation without damage the environment (Figueiredo et al., 2012; Souto et al., 2021). The energy supply is one of the main fundamentals to be overcome in the face of the growing demand for goods and/or services, which requires the use of new energy sources that are planned on the renewability and sustainability concept (Aliotte, 2020).

Solar energy, wind and biomass are some types of renewable sources, being biomass one of the most important in Brazil actually, due to the enormous potential of its use for the national energy matrix (Figueiredo et al., 2012; Costa, 2018). According to the National Energy Balance (BEN) carried out by the Energy Research Company (EPE, 2019), the electric energy generation using biomass represents $8.5 \%$ of the Brazilian electric matrix.

In the North region and Midwest region part, place with predominance of the Amazon Forest, the electrical network becomes highly impractical due to the difficult access caused by some natural obstacles, i.e., rivers, lakes, flooded regions and very dense forests (Souza et al., 2015). In these regions mentioned without power supply, small thermoelectric plants that normally use fossil fuels (mainly diesel) are used, which raises the price of the energy production, in addition to be considered as a polluting agent (Santos, 2011). This process of local energy generation through generator sets, which are powered by non-renewable fuels, for example, diesel is called isolated systems (Souza et al., 2015). Therefore, the demand for new feedstocks for utilization as biofuels is growing and, among natural sources, agricultural and forest residues are highlighted by abundance and species availability (Costa, 2018). The use of biomasses in these regions will reduce the dependence on fossil fuels, having as positive factors non-elimination of polluting when compared to diesel and reducing the dependence on centralized generation, which is supplied by concessionaires and/or electricity relay companies (Souza et al., 2015).

Among the large amount of biomasses existing in Brazil, there is the açai fruit Euterpe oleracea, a palm tree that produces a purple colour fruit, widely used for the production of beverages and food in the North and Northeast regions (Sousa and Vieira, 2014). A great attention has been devoted to the electric energy production from this biomass, mainly in isolated communities in the North of the country, where the açai seed is largely abundant (Sousa and Vieira, 2014). According to IBGE (2019), Brazil produced 1,510,022 tons of açaí fruits. From this total production, the Pará State stands out as the largest national producer, contributing about $95 \%$.

After extracting of the açaí fruit pulp, from 85 to $95 \%$ is rejected, causing serious impacts to the environment by the improper disposal of these residues (Sousa and Vieira, 2014), harming the well-being of the local population and hygiene of the cities (Cordeiro et al., 2019). From the scenario presented a possible option to reduce these impacts and also add value to waste is the use of açaí seeds for the bioenergy generation, which can present great benefits, for instance, the greenhouse gases reduction and dependence on fossil fuels (Cunha et al., 2018). It is interesting to highlight that pyrolysis, gasification and direct combustion are some examples of the thermochemical processes that can employ this biomass as a solid biofuel (Sousa and Vieira, 2014).

This study evaluated the main effects of the thermal degradation process of açai seeds Euterpe oleracea under oxidizing atmosphere (synthetic air) using Thermogravimetry/Derivative of Thermogravimetry (TG/DTG curves) and Differential Thermal Analysis (DTA curve). The physicochemical properties of the samples were evaluated using ultimate, proximate and 
calorimetric analyzes. The structural properties were evaluated by X-Ray diffraction (XRD) and Fourier transform infrared spectroscopy (FTIR). The textural and morphological aspects were characterized by scanning electron microscopy (SEM) and the composition and quantification of metals and/or inorganics was studied by optical emission spectrometry with inductively coupled plasma (ICP-OES).

Finally, this paper present a brief introduction and literature review about the studied theme, the materials and methods used to obtain the results, the main results reached in this research and conclusions.

\section{LITERATURE REVIEW}

\subsection{Biomass}

The development of new technologies provides more comfort and convenience to modern society, but these technologies increase the demand for different energy sources, which are used for the goods and/or services production (Ong et al., 2020). The dependence on fossil fuels on a global scale and high level of greenhouse gases in the environment showed a considerable increase and, to reverse this situation, several attempts are performed to identify new and promising alternative sources that present considerable cost-effectiveness (Rambo et al., 2015). Regarding, biomass is highlighted as an alternative fuel for obtaining clean energy, contributing in a beneficial way to reduce the greenhouse gases and environmental pollution (Benedito, 2012). Any renewable material derived from organic materials of animal or vegetable origin is denominated biomass (Rangel, 2014), such as wood from forests, plantations, algae, material remaining from agricultural and forestry processes, and industrial, human and animal organic residues (Saidur et al., 2011; Cruz and Crnkovic, 2015).

The energy from plant biomass, animals and/or lignocellulosic materials is obtained from the solar source through photosynthesis process. In this process, the carbon dioxide $\left(\mathrm{CO}_{2}\right)$ present in the environment is transformed into a sugar reserve and stored in plants, animals or in the respective residues, called bioenergy reservoirs (Mckendry, 2002; Babu, 2008; Saidur et al., 2011). When this biomass is totally burned or submitted to direct combustion, see figure 1, the amount of carbon dioxide produced is equal to the amount removed from the atmosphere during its growth stage, without addition of carbon dioxide $\left(\mathrm{CO}_{2}\right)$, i.e., is an emission considered neutral for this pollutant and also known as the carbon life cycle (Saidur et al., 2011).

For Cortez et al. (2008), the biomass sources are divided into woody (wood) and non-woody (saccharides, cellulosic, among others), organic residues (agricultural, urban and industrial) and biofluids (vegetable oils). Therefore, it is extremely important to know the characteristics of the biomasses used to determine the most appropriate process in which this feedstock will be used for transformation into bioenergy (Rangel, 2014).

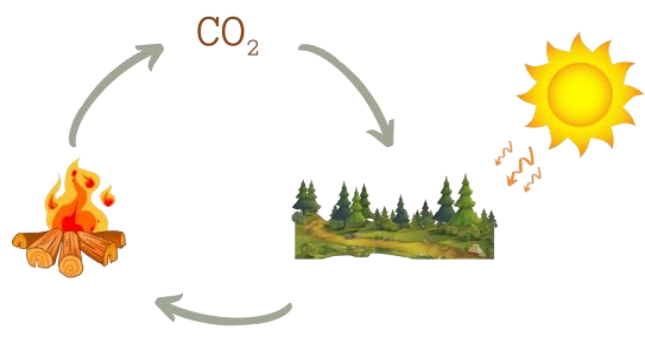

Figure 1: Carbon life cycle Representation. 


\subsection{Açaí Seeds (Euterpe oleracea) and applications}

The açai seeds (Figure 2) come from a palm tree native to the North region of Brazil, occurring mainly in the States of Pará, Amazonas, Maranhão, and Amapá, also encompassing regions in other countries, for instance, Guyana and Venezuela (Oliveira et al., 2007).

The açai tree can be identified as the palm with the greatest cultural, economic and social importance in the North region and demand for the pulp of this fruit is growing among local residents and tourists, due to the high nutritional power (Queiroz and Melém Jr., 2001). According to the IBGE (2019), Brazil produced 1,510,022 tons of açaí. From this total production, the Pará State stands out as the largest producer, totaling $95 \%$.

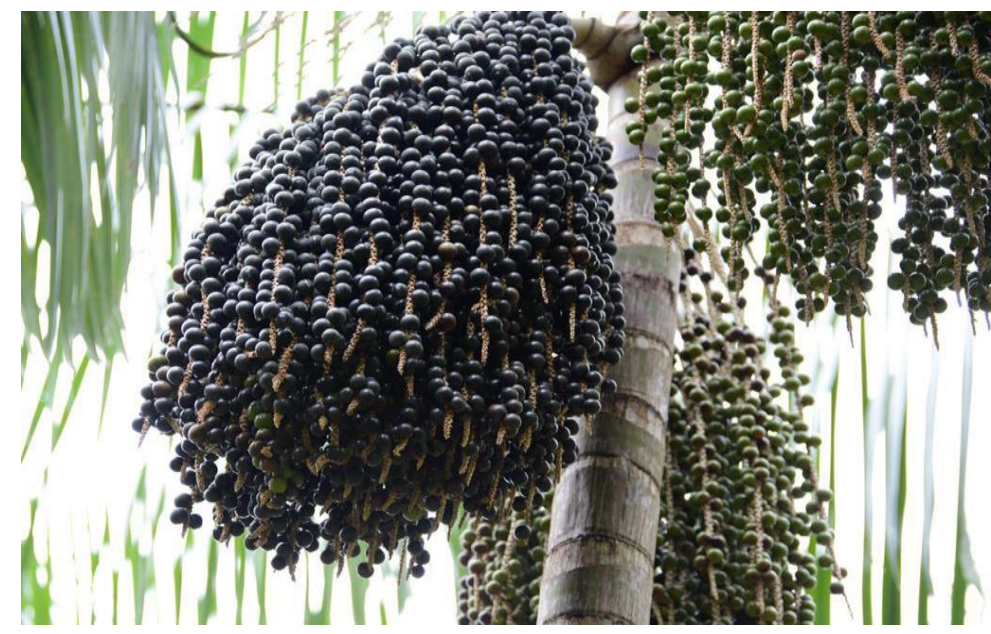

Figure 2: Palm tree of the açaí fruits.

From the açaizeiro fruits, 85 to $95 \%$ is defined as waste and causes serious impacts to the environment due to inadequate disposal in open places or burnt in the field itself (Sousa and Vieira, 2014), harming the well-being of the population and hygiene cities due to the bad smell and probable contamination by venomous animals (Cordeiro et al., 2019). Cordeiro et al. (2019) used açaí seed in natura for the production of second generation ethanol by means of enzymatic hydrolysis. The authors found that the biomass studied was promising for obtaining secondary ethanol, with a yield of $87.08 \%$ in relation to the initial glucose concentration $\left(13.68 \mathrm{~g} \mathrm{~L}^{-1}\right)$.

Martins et al. (2009) used mesocarp fiber and açaí fruit core for use in composite materials. The thermal behavior of the açai fiber proved to be similar to the main natural fibers already used industrially, such as sisal and coconut from the beach.

Ferreira et al. (2018) used the açaí residues as a coarse aggregate for the composition of a permeable concrete and concluded that, despite the lower strength of the concrete, cannot be employed as structural concrete, but it proved to be satisfactory and applicable in other demands of civil construction, for example, coating or floor.

\subsection{Thermochemical conversion processes}

A possible option to reduce environmental impacts and also add value to wastes is to use them in the clean energy generation, bringing great benefits, for example, the reduction of greenhouse gases and dependence on fossil fuels (Cunha et al., 2018). Gasification, pyrolysis and combustion are the most common thermal processes in the thermochemical conversion of different biomasses as solid biofuels (Sousa and Vieira, 2014). 
Pyrolysis represents the thermal decomposition process of biomasses in the total absence of oxygen or in a controlled ambient of nitrogen or other inert gases for products generation in the gas phase ( $\mathrm{CO}, \mathrm{CO}_{2}$, hydrogen and low molar mass hydrocarbons), liquids (tar, obtained from gas condensation), and solids (biochar or biocoal) (Félix et al., 2017; Qiao et al., 2020).

In gasification occurs an incomplete reaction between the feedstock (biomass and fossil fuels, in solid or liquid state) and oxidizing agent (oxygen), producing a gases mixture, which still present combustible properties and are called synthesis gas or simply syngas (Sousa and Vieira, 2014; Vital et al., 2018), which can be used for the heat production or in engines for electricity generation, following the proportion: $80 \%$ gas, $20 \%$ diesel or $100 \%$ gas in Otto cycle engines (Muniz and Rocha, 2013).

Direct combustion occurs in the presence of atmospheric or synthetic air (oxidizing atmosphere), producing heat and/or electricity and, when applied to lignocellulosic biomasses, successive complex chemical reactions (heterogeneous and homogeneous) can occur, whose chemical energy obtained through photosynthesis is transformed into hot gases, i.e., noncondensable gases that still contain a high calorific value (Silva et al., 2021).

\section{MATERIAL AND METHODS}

\subsection{Samples preparation}

The açaí seeds were provided by a point of sale of this delicacy at a popular market in the city of São Luís (Maranhão State, Northeast region, Brazil), located at 2²9'32.7' South (latitude) and $44^{\circ} 13^{\prime} 10.9^{\prime}$ 'West (longitude). In the preparation stage (Figure 3a-b), the samples were washed in running water to remove impurities, dried in an oven (average temperature of $60{ }^{\circ} \mathrm{C}$ for $48 \mathrm{~h}$ ) for removal excess moisture, subjected griding in a ball mill and sieving for the granulometry selection $\leq 300 \mu \mathrm{m}$ (average particle size).
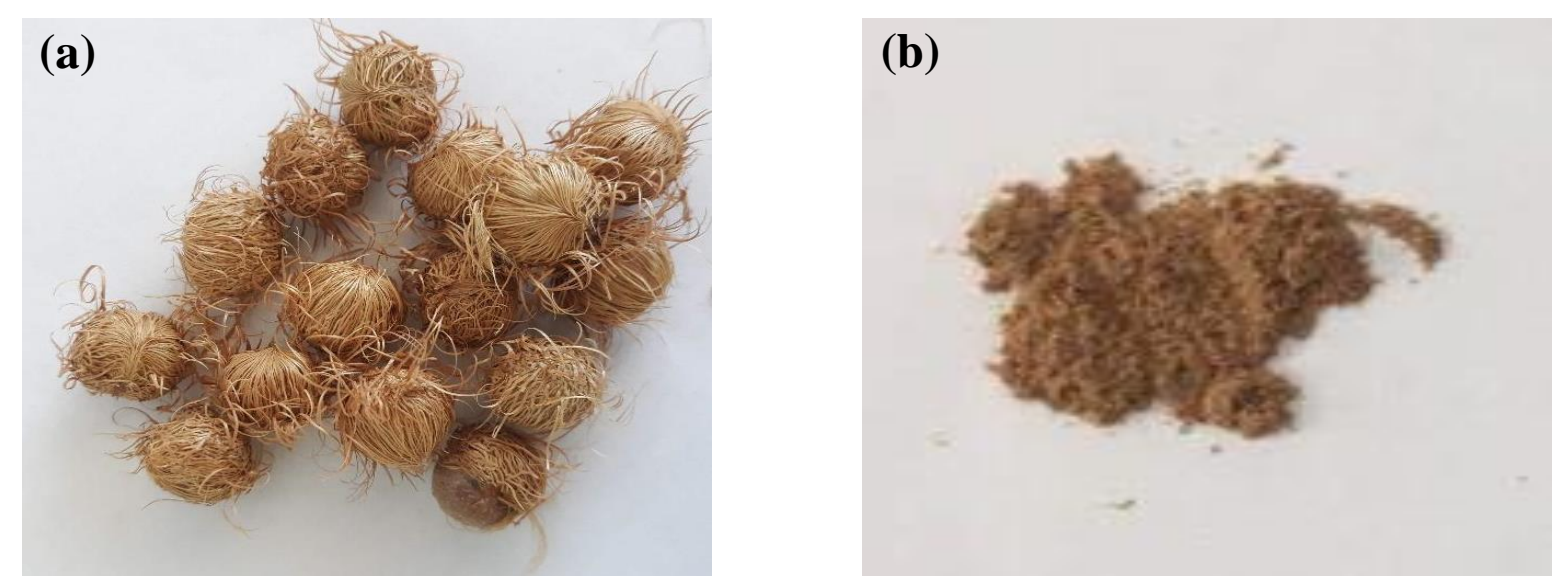

Figure 3: Açaí seeds samples: (a) after washed and dried, and (b) after griding and sieving - average granulometry ( $\leq$ $300 \mu \mathrm{m})$.

\subsection{Proximate analysis}

The moisture content (W), volatile materials (VM), fixed carbon (FC), and ash (A) of the açaí seeds samples were obtained by Thermogravimetric analysis in a simultaneous SDT 2960 TGA-DTA equipment, based on the methodology developed by Torquato et al. (2017). 


\subsection{Ultimate analysis}

The relative content of carbon $(\mathrm{C})$, hydrogen $(\mathrm{H})$, nitrogen $(\mathrm{N})$, and sulfur $(\mathrm{S})$ present in the biomass were quantified in a 2400 CHNS-O Elementar Analyzer (Perkins Elmer brand). The oxygen content (O) was calculated by difference at $100 \%$, on a dry and ash-free basis (Protásio, 2014).

\subsection{Calorimetry analysis (HHV/LHV)}

The higher heating value (HHV) of the açaí seeds was determined in a IKA C200 calorimeter pump, and the Equation 1 was used to calculate the lower heating value (LHV) (Cortez et al., 2008).

$$
L H V=(H H V-\lambda *(r+0.09 * H) \lambda) *(100-W) / 100
$$

Where $\lambda$ is the latent heat of water vaporization $\left(2.31 \mathrm{MJ} \mathrm{kg}^{-1}\right)$ at $25^{\circ} \mathrm{C}, \mathrm{W}$ is the moisture contained in sample calculate by proximate analysis, $\mathrm{H}$ is the hydrogen content obtained from the ultimate analysis and $r=W /(100-W)$, wich is denominated of moisture ratio.

\subsection{Thermal analysis (TG/DTG and DTA curves)}

For the thermogravimetric analysis/derivate thermogravimetric (TGA/DTA curves) and differential thermal analysis (DTA) was used a SDT 2960 Simultaneous TGA-DTA thermal analyzer, whose experimental conditions were: dynamic atmospheric flow of $100 \mathrm{~mL} \mathrm{~min}{ }^{-1}$ under air atmosphere synthetic, using a sample mass of $7.16 \pm 0.01 \mathrm{mg}$ and a heating rate of $10^{\circ} \mathrm{C} \mathrm{min}{ }^{-1}$ from room temperature to $800^{\circ} \mathrm{C}$.

\subsection{X-Ray diffraction (XRD)}

For determination the crystallographic structure of the samples, a Shimadzu brand diffractometer (XRD-6000 model) was used. The $2 \theta$ (diffraction angle) ranged from $10^{\circ}$ to $90^{\circ}$, employing $\mathrm{CuK} \alpha$ radiation $(\lambda=1.541 \AA)$, voltage $40 \mathrm{kV}$, current $40 \mathrm{~mA}$ and a step size $0.05^{\circ} \mathrm{s}^{-1}$.

The Crystallinity Index (CI) was calculated by Equation 2 based on the crystalline region intensity $\left(\mathrm{I}_{002}\right)$, with peak at $2 \theta=22.5^{\circ}$, and the amorphous region intensity $\left(\mathrm{I}_{\mathrm{am}}\right)$, with $2 \theta=18^{\circ}$ (Cruz et al., 2018).

$$
I C=100 *\left(I_{002}-I_{a m}\right) / I_{002}
$$

\subsection{Fourier transform infrared spectroscopy (FTIR)}

The FTIR spectra of the samples were obtained by means of Shimadzu Fourier transform spectrophotometer (IR-Prestige-21 model). The analyses were carried out in potassium bromide (KBr) pellets and a wavelength ranging from 4000 to $400 \mathrm{~cm}^{-1}$.

\subsection{Determination of metal composition (ICP-OES)}

In order to quantify metallic and inorganic elements of açaí seeds, an inductively coupled plasma - optical emission spectrometer (ICP-OES) was used, with concentration reaching up to 10 $\mathrm{mg} \mathrm{L}^{-1}$ for certain elements analyzed (Caruso et al., 2017).

\subsection{Scanning electron microscopy (SEM images)}


The morphological and textural characteristics of the açaí seeds samples were evaluated by SEM images, obtained on a Tescan Vega 3 Scanning Electron Microscope, with 1000 and 5000 times of magnification.

\section{RESULTS AND DISCUSSION}

\subsection{Proximate, Ultimate and Calorimetric Analysis}

By means of the ultimate analysis (Table 1), and based on the levels of carbon, hydrogen, oxygen, nitrogen and sulfur were obtained, the chemical formula for the açaí seeds was constructed, i.e., dividing the quantified percentage of each element $(\mathrm{C}, \mathrm{H}, \mathrm{O}, \mathrm{N}, \mathrm{S})$ by the respective atomic weights (Cruz et al., 2021). From the chemical formula $\left(\mathrm{C}_{3.89} \mathrm{H}_{5.18} \mathrm{~N}_{0.05} \mathrm{O}_{2.96}\right)$ obtained for this lignocellulosic compound, it is possible to predict the yield of the complex chemical reactions during thermal decomposition and also estimate the gaseous emissions of these materials when subjected to thermochemical processes (Braz, 2014).

Table 1: Proximate, ultimate and calorimetric analysis of açaí seeds Euterpe oleracea.

\begin{tabular}{|c|c|}
\hline \multicolumn{2}{|c|}{ Ultimate Analysis } \\
\hline Element & Quantitative (\%) \\
\hline Carbon (C) & $46.72 \pm 0.50$ \\
\hline Hydrogen $(\mathrm{H})$ & $5.18 \pm 0.17$ \\
\hline Oxygen $(\mathrm{O})^{*}$ & $47.42 \pm 0.65$ \\
\hline Nitrogen $(\mathrm{N})$ & $0.68 \pm 0.03$ \\
\hline Sulfur (S) & n.d. \\
\hline \multicolumn{2}{|c|}{ Chemical Formula } \\
\hline \multicolumn{2}{|c|}{$\mathrm{C}_{3.89} \mathrm{H}_{5.18} \mathrm{~N}_{0.05} \mathrm{O}_{2.96}$} \\
\hline \multicolumn{2}{|c|}{ Proximate Analysis } \\
\hline Moisture & $10.00 \%$ \\
\hline Volatile Materials & $63.00 \%$ \\
\hline Fixed Carbon & $26.00 \%$ \\
\hline Ash & $1.00 \%$ \\
\hline
\end{tabular}

\section{Calorimetric Analysis (MJ kg-1)}

Higher Heating Value (HHV) Lower Heating Value (LHV)

$* O=100-(\% C+\% H+\% N+\% S) \mathrm{O}=100-(\% \mathrm{C}+\% \mathrm{H}+\% \mathrm{~N}+\% \mathrm{~S})$
n.d. $=$ not detected or below of the equipment detection limit.

The biomass of açaí seeds showed an average carbon value (46.72\%), close to the values 48.47\% and $47.41 \%$ found for this same biomass by Costa (2018) and Virmond et al. (2012), respectively, , and twice as high in relation to the value found by Silva et al. (2019) for the fish scales $(20.32 \%)$. Such proportions reflect directly on the elevated Higher Heating Value (HHV), i.e., $19.75 \mathrm{MJ} \mathrm{kg}^{-1}$, which increases linearly with this constituent (Costa, 2018). Carbon, hydrogen and oxygen are the major components in solid fuels, reacting during combustion in an exothermic reaction and generating mainly $\mathrm{CO}_{2}$ and $\mathrm{H}_{2} \mathrm{O}_{(\mathrm{v})}$, which contributes positively to the increase in HHV (Sasmal et al., 2012; Braz, 2014; Cruz et al., 2018).

On the other hand, higher levels of oxygen $(\mathrm{O})$ present in the samples reduce the HHV of a biofuel, mainly due to the enthalpy values of the bonds, since a high energy is necessary to occur 
break in the bonds formed by oxygen atoms (Braz, 2014). Despite the high oxygen content (47.42\%), the açaí seeds presented a high HHV value, slightly higher than that found by Cruz et al. (2021) and Cruz et al. (2018) for the cassava leaves (18.86 $\mathrm{MJ} \mathrm{kg}^{-1}$ ) and sugarcane bagasse (17.47 $\mathrm{MJ} \mathrm{kg}^{-1}$ ), respectively. It is worth mentioning that this latter biomass is widely used for the electric energy generation in biorefineries, a factor that corroborates with the use of açaí seeds can be applied in thermochemical conversion processes for the of clean energy generation.

For açaí seeds residues, the Lower Heating Value (LHV) was $16 \%$ lower in relation to the HHV of this same biomass. This value was twice higher than found for the fish scale samples (8.17 MJ kg ${ }^{-1}$ ) conform studied by Silva et al. (2019). The LHV is given by energy released in the oxidation of a fuel without taking into account the water latent heat and, therefore, this value is important and considered during the development of thermal process projects for the power generation (Mckendry, 2002; Braz, 2014; Costa, 2018).

The levels of nitrogen $(\mathrm{N})$ and sulfur $(\mathrm{S})$ are necessary parameters for the knowledge of the formation potential of polluting agents, resulting from the biomasses thermal degradation, during burning, which are emitted to the atmosphere and can cause damage to the environment and health human (Ren et al., 2017; Costa, 2018). The residues of the açaí fruits presented nitrogen as a minor component, i.e., $0.68 \%$. Lower values of this element are suitable for the combustion process, since nitrogen in high quantities can react with oxygen in the atmospheric air, forming $\mathrm{NO}_{\mathrm{x}}(90 \% \mathrm{NO}$, $10 \% \mathrm{NO}_{2}$ and $\mathrm{N}_{2} \mathrm{O}$ in minority), gases responsible for the occurrence of acid rain and problems of corrosion in industrial equipments (Cruz et al., 2021).

The açaí seeds, as well as the sugarcane bagasse samples investigated by Braz (2014) and Cruz (2015), not presented a sulfur content in the elemental composition, being less prone to the production of polluting gases. Sulfur, during gasification, is converted into hydrogen sulfide $\left(\mathrm{H}_{2} \mathrm{~S}\right)$, a highly corrosive gas used in coolers, and that causes serious damage to transfer systems or heat exchangers (Virmond et al., 2012). In addition, the formation of $\mathrm{SO}_{2}$ can lead to corrosion processes in industrial plants, reducing the useful life of the metallic materials and affecting the efficiency or performance of the thermal process, and as $\mathrm{NO}_{\mathrm{x}}$ gases, are also responsible for the occurrence of acid rain (Braz, 2014; Wang et al., 2017).

The moisture content for the açaí seeds was approximately $10 \%$, being considered as a dry biomass (Braz, 2014). Moisture decreases the fuel quality, delaying ignition and, consequently, impairing combustion (Medeiros, 2016). For the gasification process, a moisture inferior $10 \%$ in the fuels is favorable, since wetter samples (greater than 50\%) can damage the equipments due to the tar formation, which results in poor ignition and difficulty in the combustion process (Braz, 2014; Barbosa et al., 2016).

The volatile materials content for a determined biomass depend on its nature and are in the range from 75 to $90 \%$ (Cruz et al., 2021). The volatile material content is used to determine the ignition easily and burning of solid fuels. Together with the fixed carbon and volatile material ratio, which determines the flame stability during combustion, revealing that the higher the material volatile content, the higher the burning velocity and the lower flame stability (Virmond et al., 2012; Medeiros, 2016). The high values of volatile materials in biomasses show its high reactivity (Braz, 2014), demonstrating a representativeness of the tar content in the combustion gases and rapid ignition (Marcelino, 2017).

According to Yang et al. (2005) for the plant biomasses the fixed carbon varies from 7 to $20 \%$. The high fixed carbon content of açaí seeds (23\%) showed a high thermal resistance of this biomass, i.e., combustion process will occur more slowly (Marcelino, 2017). It is worth mentioning that materials that present a high fixed carbon content also have a high heating value, which is an 
important parameter for the gasification process evaluation, since from this parameter it is possible to determine the process velocity rate and the respective thermal yield (Medeiros, 2016).

The low ash content found for the açai seed samples $(\approx 1 \%)$ makes them an excellent residue with great possibility of be used in thermochemical conversion processes, since the excess ash impairs the use of some lignocellulosic materials in industrial processes, causing problems such as slurry, agglomeration, slag, and deposition on the walls of the equipments and, consequently, decrease in the thermal process efficiency (Braz, 2014).

\subsection{Thermal analysis (TG/DTG and DTA curves)}

Thermogravimetry (TG) and Derivative of Thermogravimetry (DTG) (Figure 4a) were performed under oxidizing atmosphere or synthetic air (combustion), showing the main of thermal degradation stages for the açai seeds samples. The first stage is comprised between $40^{\circ}$ and $150{ }^{\circ} \mathrm{C}$, with a peak of mass loss in approximately $60{ }^{\circ} \mathrm{C}$. This phase corresponds to the moisture release from biomass, with a mass loss of approximately $10 \%$ (Costa, 2018). The biomass moisture content should be limited a range from 10 to $30 \%$ weight, in order to avoid ignition and combustion problems in actual thermal processes (Virmond et al., 2012).

The second stage, between $180{ }^{\circ} \mathrm{C}$ and $370{ }^{\circ} \mathrm{C}$, is due to the detachment of highly volatile components, which are associated to the thermal decomposition of cellulose, hemicellulose and initial lignin part (Virmond et al., 2012). This is a region of rapid combustion, where the maximum mass loss rate reached a value of approximately 50\%, indicating a peak temperature at $290{ }^{\circ} \mathrm{C}$ (Virmond et al., 2012). The mass loss was higher than the value found by Fraga and Tavares (2017) for the açai fibers in natura (40\%), which occurred in the range from $200^{\circ}$ to $325^{\circ} \mathrm{C}$. The second peak observed in this stage was considered as thermal degradation of cellulose and hemicellulose simultaneously, denominated holocellulose and characterized by the presence of a "shoulder" in TG curve around $320^{\circ} \mathrm{C}$ (Silva, 2019).

The third stage, starting at around $370{ }^{\circ} \mathrm{C}$ and ending at $530{ }^{\circ} \mathrm{C}$, showed a peak at $440{ }^{\circ} \mathrm{C}$, which is related to the thermal degradation of residual lignin. For Braz (2014), lignin thermal decomposition starts at around $200{ }^{\circ} \mathrm{C}$ and ends at $600{ }^{\circ} \mathrm{C}$. Lignin presents a high thermal stability, which makes it difficult to decompose at temperatures below $600{ }^{\circ} \mathrm{C}$ (Fraga and Tavares, 2017). In this stage, the mass loss was approximately $36 \%$.
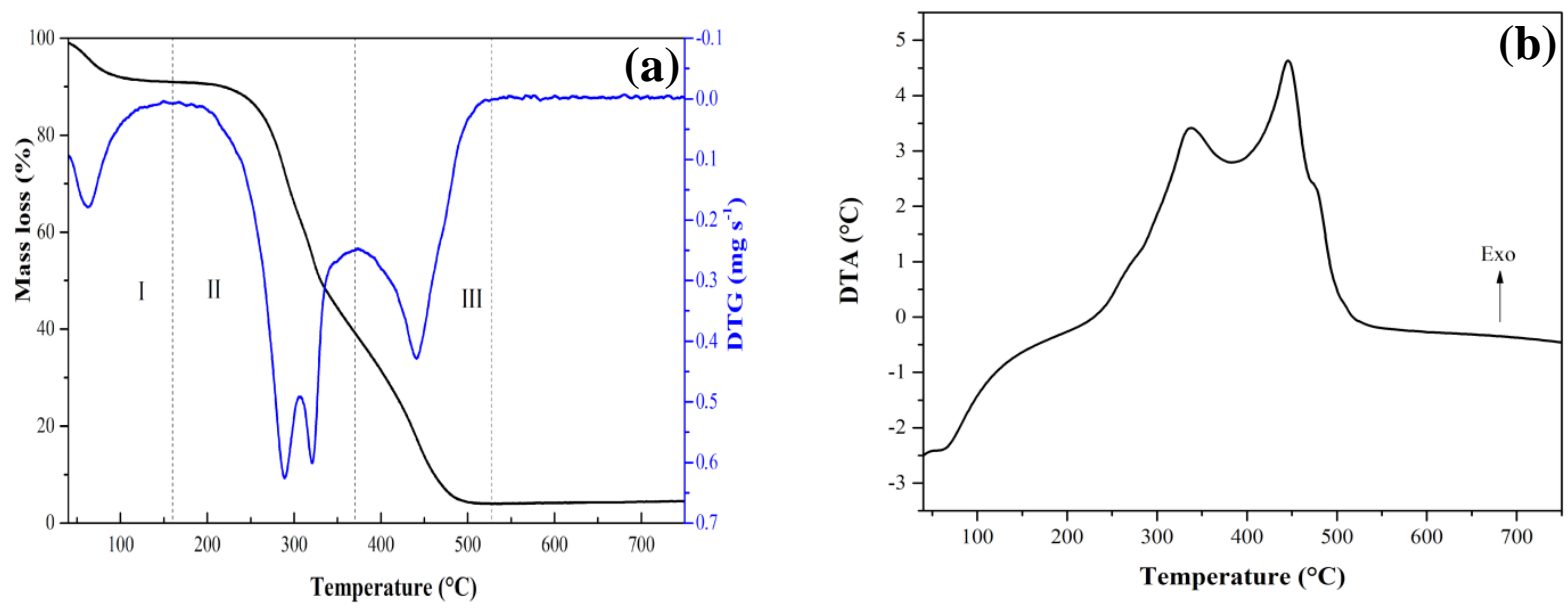

Figure 4: Curves (a) TG/DTG and (b) DTA under oxidizing atmosphere (synthetic air) for açaí seed Euterpe oleracea.

After $600{ }^{\circ} \mathrm{C}$, the residues generated or ashes (inorganic and metals) resulting from the burning of the açaí seeds were approximately 4\%. How much more reactive the biomass, lower temperature and residence time are required for its complete thermochemical conversion, which 
reduces the problems caused by the ashes, since at high temperatures $\left(900-1050{ }^{\circ} \mathrm{C}\right)$ these are melted and in contact with the airflow can solidify, causing sintering problems on the equipment's thermal surfaces (Virmond et al., 2012). Fluidized bed gasifiers, for example, operate at temperatures below the melting temperatures of the biomass ashes, i.e., $900{ }^{\circ} \mathrm{C}$, which is a good option for the use of açaí seeds in the bioenergy generation (Virmond et al., 2012).

By means of DTA curve (Figure 4b), the endothermic (heat gain) and exothermic (heat loss) events related to the thermal degradation of açai seeds under oxidizing atmosphere were observed. The endothermic process occurred at $62{ }^{\circ} \mathrm{C}$, and is related to the moisture evaporation from the samples. The exothermic peaks verified at 337 and $445{ }^{\circ} \mathrm{C}$ are in accordance with the mass loss events shown in the TG/DTG curves, which are related to the thermal degradation of holocellulose $\left(320^{\circ} \mathrm{C}\right)$ and residual lignin $\left(440{ }^{\circ} \mathrm{C}\right)$.

In addition, for all the aforementioned thermal and physical-chemical characteristics, other factors, such as environmental and socioeconomic aspects, could also demonstrate that açaí seeds are a prone and strong candidate for use as a feedstock in the bioenergy production through thermochemical processes (combustion, pyrolysis and gasification), but noting that generalizations cannot be made when different lignocellulosic biomasses are used in thermoconversion processes.

\subsection{X-Ray diffraction (XRD)}

From the X-ray diffractogram (Figure 5), it is possible to observe the crystalline effect of vegetable fibers, corresponding to the cellulose fraction with the most intense peak around $22^{\circ}$ and referring to the planes of the glycosidic rings (sugars and carbohydrates), which are denser and contain type I cellulose (Fraga and Tavares, 2017), while the peak around $18^{\circ}$ refers to the amorphous region (Cruz et al., 2018).

The crystallinity index (CI) for açaí seeds was calculated by Equation 2, which presented a value of 23\%, and is slightly lower than that found by Rambo, Schmidt and Ferreira (2015) for the açaí seeds (30\%), indicating that the açaí seeds studied presented around $77 \%$ of amorphous regions in their structural composition. It is a biomass with low crystallinity when compared with other biomasses studied by other authors, for instance, tucuma seed $(\mathrm{CI}=57.4 \%)$, sugarcane bagasse $(\mathrm{CI}=64.8 \%)$ (Cruz et al., 2018) and the cassava stem $(\mathrm{CI}=60.2 \%)(\mathrm{Cruz}$ et al., 2021).

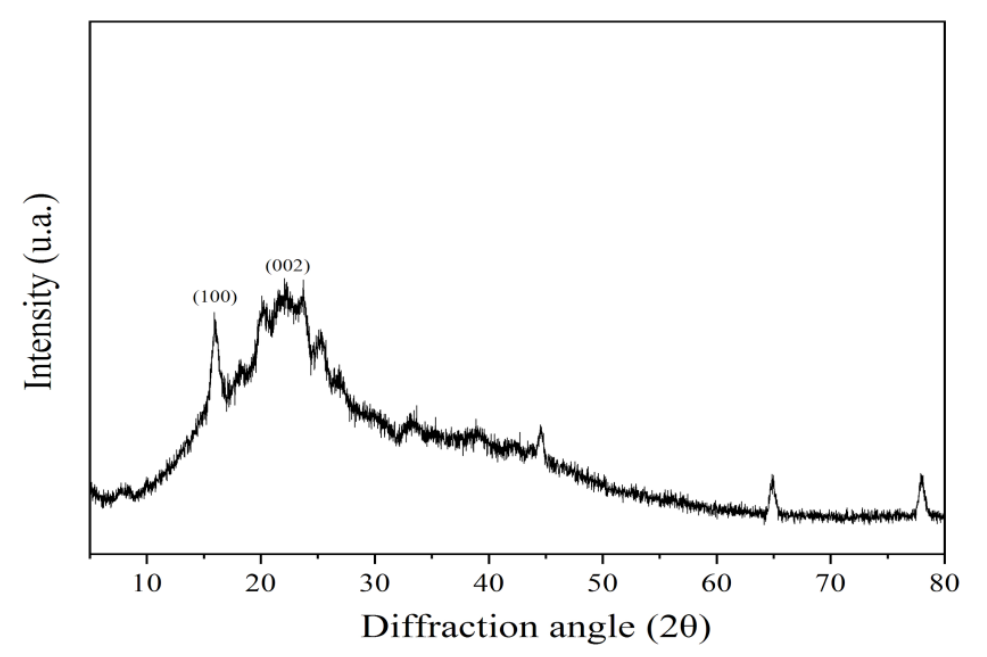

Figure 5: X-Ray Diffractogram of açaí seed Euterpe oleracea.

Biomasses with characteristics amorphous are more reactive when compared to crystalline ones, since the absence of crystalline agglomerates makes these lignocellulosic materials more 
susceptible to complex reactions of thermal degradation (Silva et al., 2019), or are easier to be accessed by chemical treatments or biological factors (Cruz et al., 2018).

\subsection{Fourier transform infrared spectroscopy (FTIR)}

From the infrared spectrometer (Figure 6), the main functional groups present in açai seeds were identified (Table 2). According to Martelli (2014), the application of this analysis allows the identification of some molecular structures, such as aliphatic, aromatic and peptide components, and reactive functional groups, e.g., $\mathrm{COOH}, \mathrm{OH}, \mathrm{C}=\mathrm{O}$ and $\mathrm{NH}_{2}$.

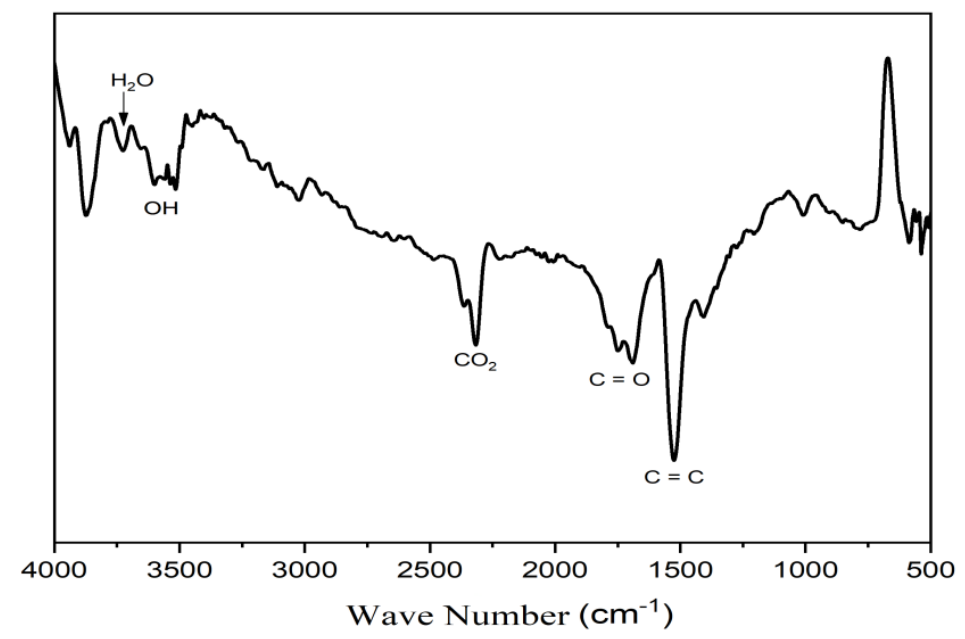

Figure 6: Fourier Transform Infrared Spectrometer for the açaí seeds Euterpe oleracea.

The region between 3750 to $3500 \mathrm{~cm}^{-1}$ can be directly related to water molecules (Lisbon, 2016). For the 3700 to $3400 \mathrm{~cm}^{-1}$ region, with maximum value around $3432 \mathrm{~cm}^{-1}$, a wide range of absorption and intensity may be related to the valiant vibrations of the $\mathrm{OH}$ linkage between the water and hydrogen molecules or to the $\mathrm{OH}$ groups present in cellulose, hemicellulose and lignin (Oliveira et al., 2019; Silva et al., 2019). The peaks in the 2400 to $2250 \mathrm{~cm}^{-1}$ range were attributed to the $\mathrm{C}=\mathrm{O}$ bonds of the $\mathrm{CO}_{2}$ group (Kok et al., 2017; Musellim et al., 2018; Silva et al., 2019). The bands in the $1730 \mathrm{~cm}^{-1}$ region can be associated to the $\mathrm{C}=\mathrm{O}$ elongation (vibration of aliphatic carboxylic acids and ketones), mainly due to the hemicellulose and carbonyl conjugated groups in the lignin, which are close to $1650 \mathrm{~cm}^{-1}$ (Cruz et al., 2018; Oliveira et al., 2019). Between 1600 and $1500 \mathrm{~cm}^{-1}$, the $\mathrm{C}=\mathrm{C}$ band of aromatic skeletal vibrations appears on lignin (Cruz et al., 2018).

Table 2: Main functional groups found for the açaí seeds Euterpe oleracea.

\begin{tabular}{|c|c|}
\hline Components & Wavenumber $\left(\mathrm{cm}^{-1}\right)$ \\
\hline $\begin{array}{c}\mathrm{OH} \text { bond between water and hydrogen molecules or } \mathrm{OH} \text { groups of } \\
\text { cellulose, hemicellulose and } \mathrm{OH} \text { lignin }\end{array}$ & $3700-3400$ \\
\hline $\begin{array}{l}\text { Cluster } \mathrm{C}=\mathrm{O} \text { due to hemicellulose and conjugated carbonyl groups } \\
\text { in lignin }\end{array}$ & $2400-2250$ e 1730 \\
\hline $\mathrm{C}=\mathrm{C}$ cluster of aromatic skeletal vibrations that appear in lignin & $1600-1500$ \\
\hline
\end{tabular}

\subsection{Determination of metal composition (ICP-OES)}

From the analysis of ICP-OES it was possible to quantify the main inorganic and metallic elements present in the açaí seeds samples (Figure 7). The biomass ashes present some inorganic elements, such as sodium $(\mathrm{Na})$, potassium $(\mathrm{K})$, magnesium $(\mathrm{Mg})$, phosphorus $(\mathrm{P})$, and calcium $(\mathrm{Ca})$ that form complex compounds and are especially important during thermochemical conversion 
process (Mlonka-Medrala et al., 2020). These elements present in biomass are widely studied due to their significant influence on slag, slurry, agglomeration, corrosion and pollutants formation (Williams et al., 2012).

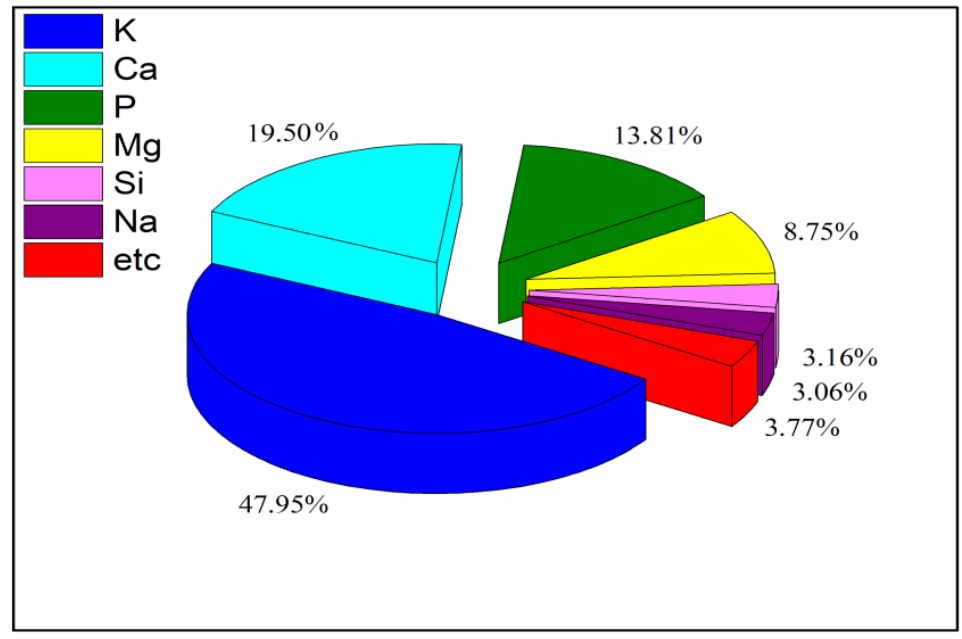

Figure 7: Main inorganic and/or metallic elements present in the açaí seeds samples Euterpe oleracea by ICP-OES.

A relatively high amount of potassium (K) was found for the of açaí seeds samples $(2520$ $\left.\mathrm{mg} \mathrm{kg}^{-1}\right)$. The açaí fruits present high energy content and nutritional properties, with the presence of some minerals, e.g., phosphorus (P), potassium (K), and calcium (Ca) (Sato, 2018). During the biomass combustion process, potassium is released in the gas phase and then, the flue gases are cooled on the ovens surfaces, condensing and forming potassium chloride $(\mathrm{KCl})$ and potassium hydroxide $(\mathrm{KOH})$, compounds that cause fouling and corrosion in metal parts when subjected to high temperatures, in addition to the possible adherence of these compounds to the ashes generated in the burning (Mason et al., 2016).

Calcium (Ca) (1025 mg kg$\left.{ }^{-1}\right)$ and magnesium (Mg) (460 mg kg-1) were also found in the biomass sample studied. Since these elements are essential nutrients for the vegetables, a possible advantage of the presence of $\mathrm{K}, \mathrm{Ca}$, and $\mathrm{Mg}$ in biomasses would be the possibility of use the ashes from these samples as fertilizers or soil conditioners (San Miguel et al., 2012; Cruz et al., 2018).

Some metals quantified in smaller proportions (3.8\% total composition), for instance, $\mathrm{Fe}$, $\mathrm{Mn}, \mathrm{Cu}$, and $\mathrm{Pb}$ were also identified. A potentially toxic element i.e., lead $(\mathrm{Pb})$ was detected with a value $3 \mathrm{mg} \mathrm{kg}^{-1}$, which is considered non-significant. However, cadmium (Cd) and arsenic (As) elements were not detected, showing that the use of açaí seeds for bioenergy generation through thermochemical processes not represent environmental and/or human health risks (Cruz et al., 2021).

\subsection{Scanning electron microscopy (SEM images)}

From the analysis of the scanning electron microscopy (Figure 8a-d) it was possible to observe that the açaí seeds showed a highly compacted structure, with meso and macropores, in addition to the formation of larger aggregates of particles on the surfaces (Pessoa et al., 2019). The fibers of the açaí seeds showed an isotropic property, i.e., these samples exhibited an ordered distribution and elongated chain with the same direction and sense (Cruz et al., 2018). The irregular surfaces of the samples may be associated with the possible deformation caused during the crushing process and/or the friction between the biomass particles themselves (Barbosa et al., 2019), or can also be a natural shape of the açaí seeds. 


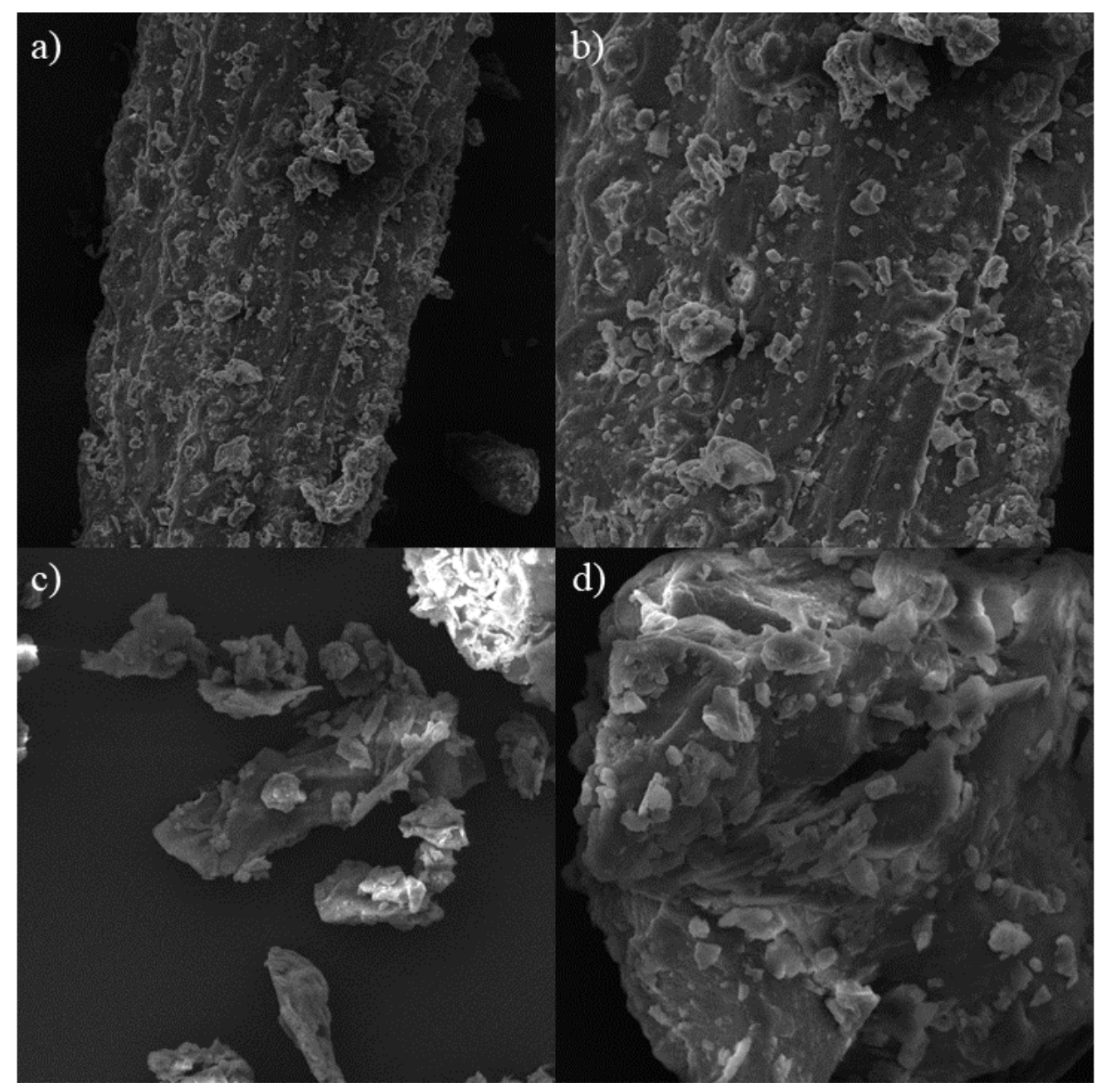

Figure 8: Scanning Electron Microscopy for the açaí seeds Euterpe oleracea, with amplitudes: a) 1000x, b) 2000x, c) $2500 x$, and d) 5000x.

\section{CONCLUSIONS}

Açaí seeds were studied by means of physical-chemical characteristics and thermal behavior to use this biomass in thermochemical processes for the clean energy generation. The açaí residues presented a high carbon content, resulting in a considerable Higher Heating Value (HHV). Sulfur and nitrogen contents were not significant, making the studied biomass less prone to the air polluting emissions during the burning process in an oxidizing atmosphere. The quantification of metals and/or inorganics showed a high potassium $(\mathrm{K})$ content in the samples, which can cause incrustations in the ovens walls, which are currently controlled and/or monitored electronically by means of computational tools or softwares. Lead was detected as a trace element, however, cadmium and arsenic, highly toxic elements were not detected, not representing environmental and human health risks. The samples presented a compacted structure with meso and macropores, and formation of larger aggregates on the surfaces. The thermal behavior of the açai residues identified three distinct phases of thermal degradation, which are related to the moisture release, cellulose and hemicellulose (holocellulose) and residual lignin.

Therefore, it is understood that açaí seeds biomass showed a great potential to be applied in thermal processes for bioenergy generation. For example, the use of these residues presents advantages in the partial reduction of the dependence on fossil fuels and lower polluting gases emissions. Finally, the use of these residues can avoid their disposal in inappropriate places or infestation/contamination of venomous animals, adding high value to these residues. 


\section{ACKNOWLEDGMENTS}

The authors gratefully acknowledge Foundation for Research Support, Scientific and Technological Development of Maranhão - FAPEMA (00957/19), and National Council for Scientific and Technological Development - CNPq (426162/2018-8 and 101062/2019-2) for the financial support.

\section{REFERENCES}

Aliotte, F. F. (2020). Indicador de preço para valorização da biomassa a partir da geração de vapor no Estado de São Paulo. Dissertação (Mestrado em Agronegócio) - Escola de Economia de São Paulo, Fundação Getúlio Vargas, São Paulo.

Babu, B. V. (2008). Biomass pyrolysis: a state-of-the-art review. Biofuels, Bioproducts and Biorefining, 2 (5), $393-414$. https://doi.org/10.1002/bbb.92

Barbosa, A. M.; Rebelo, V. S. M.; Martorano, L. G.; Giacon, V. M. (2019). Caracterização de partículas de açaí visando seu potencial uso na construção civil. Revista Matéria, 24 (3), 1-11. https://doi.org/10.1590/s1517$\underline{707620190003.0750}$

Barbosa, I. R.; Barcellos, K. M.; Souza, J. E. A.; Cavalcanti, C. A. S. H.; Danta, L. P. M.; Alécio, A. H. L. (2016). Caracterização do potencial energético de biomassas. In: XXI Congresso Brasileiro de Engenharia Química. Anais Eletrônicos, Campinas, Galoá.

Benedito, T. H. S. (2012). Coleta, análise e degradação catalítica do alcatrão produzido na gaseificação de caroço de açaí e casca de arroz. Dissertação (Mestrado em Engenharia e Tecnologia Espaciais/Engenharia e Gerenciamento de Sistemas Espaciais) - Instituto Nacional de Pesquisas Espaciais, São José dos Campos.

Braz, C. E. M. (2014). Caracterização de biomassa lignocelulósica para uso em processos térmicos de geração de energia. 2014. Dissertação (Mestrado em Química) - Engenharia Química, Universidade Estadual Paulista, São Paulo.

Cordeiro, M. A.; Almeida, O.; Rodrigues, E. M. S.; Chaves Neto, A. M. J.; Machado, N. T. (2019). Produção de etanol através da hidrólise enzimática do caroço de açaí (Euterpe oleracea mart). Revista Brasileira de Energias Renováveis, 8 (1), 122-152. https://doi.org/10.5380/rber.v8il.53977

Cortez, L. A. B.; Lora, E. E. S.; Gómez, E. O. (2008). Biomassa para energia. Campinas: Unicamp.

Costa, J. S. (2018). Biomassa residual para uso energético no Estado do Pará. Dissertação (Mestrado em Ciências Florestais) - Universidade Federal Rural da Amazônia, Belém.

Cruz, G. and Crnkovic, P. M. (2015). Investigation into the kinetic behavior of biomass combustion under $\mathrm{N}_{2} / \mathrm{O}_{2}$ and $\mathrm{CO}_{2} / \mathrm{O}_{2}$ atmospheres. Journal of Thermal Analysis and Calorimetry, 123, 1003-1011. https://doi.org/10.1007/s10973$\underline{015-4908-2}$

Cruz, G.; Braz, C. E. M.; Ávila, I.; Crnkovic, P. M. (2018). Physico-chemical properties of Brazilian biomass: potential applications as renewable energy source. African Journal of Biotechnology, 1, 1-19. https://doi.org/10.5897/AJB2017.16296

Cruz, G.; Rodrigues, A. L. P.; Silva, D. F.; Gomes, W. C. (2021). Physical-chemical characterization and thermal behavior of cassava harvest waste for application in thermochemical processes. Journal of Thermal Analysis and Calorimetry, 143, 3611-3622. https://doi.org/10.1007/s10973-020-09330-6

Cunha, K. C. L.; Lima, S. S.; Oliveira, L. S.; Querino, J. K. A. S.; Ferreira, W. M. (2018). Avaliação do resíduo do açaí como fonte alternativa de energia. In: Seminário Internacional em Ciências do Ambiente e Sustentabilidade na Amazônia 5, Manaus.

Domingos, C. A.; Pereira, D. D.; Cardoso, L. S.; Teodoro, R. A.; Castro, V. A. (2012). Biodiesel - proposta de um combustível alternativo. Revista Brasileira de Gestão e Engenharia, 5, 134-178. 
EPE - Empresa de Pesquisa Energética (2019). Balanço energético nacional 2019: Ano base 2018. Rio de Janeiro, 67.

Félix, C. R. O.; Azevedo Jr., A. F.; Freitas, C. C.; pires, C. A. M.; Teixeira, V.; Frety, R.; Brandão, S. T. (2017). Pirólise rápida de biomassa de eucalipto na presença de catalisador Al-MCM-41. Revista Matéria, 22(1), 1-11. https://dx.doi.org/10.1590/s1517-707620170005.0251

Ferreira, R. S.; Silva, I. A.; Silva, R. F.; Viana, F. M. P. C.; Pereira, M. S.; Rodrigues, E. C. (2018). Análise das propriedades mecânicas do concreto permeável com incorporação de sementes de açaí. In: $3^{\circ}$ Congresso LusoBrasileiro de Materiais de Construção Sustentáveis, Coimbra. Ata do $3^{\circ}$ CLBMCS 2018.

Figueiredo, F. L.; Fernandes, F.; Petrucci, A. L.; Furini Filho, R.; Marsura, M. (2012). Produção de energia elétrica através da biomassa em sistema de gaseificação concorrente e grupo gerador com capacidade de 50 kVA. Semina: Ciências Exatas e Tecnológicas, 33 (2), 165-174. http://dx.doi.org/10.5433/1679-0375.2012v33n2p165

Fraga, L. A. and Tavares, M. I. B. (2017). Estudo de diferentes condições de mercerização das fibras da semente de açaí (Euterpe oleracea). Revista Semioses, 11 (3), 49-54. https://doi.org/10.15202/1981996X.2017v11n3p49

Kok, M. V.; varfolomeev, M. A.; nurgaliev, D. K. (2017). Crude oil characterization using TGA-DTA, TGA-FTIR and TGA-MS techniques. Journal of Petroleum Science and Engineering, 154, 537-542. https://doi.org/10.1016/j.petrol.2016.12.018

Marcelino, M. M. (2017). Biomassa residual do coco para obtenção de energia e intermediários químicos via gaseificação: caracterização, modelagem e simulação. Dissertação (Mestrado em Engenharia Industrial) - Universidade Federal da Bahia, Salvador.

Martelli, F. H. (2014). Determinação e caracterização físico-química e espectroscópica de gramíneas para obtenção de etanol de segunda geração. Dissertação (Mestrado em Química Analítica e Inorgânica) - Universidade de São Paulo, São Carlos.

Martins, M. A.; Mattoso, L. H. C.; Pessoa, J. D. C. (2009). Comportamento térmico e caracterização morfológica das fibras de mesocarpo e caroço do açaí (Euterpe oleracea mart.). Revista Brasileira de Fruticultura, 31 (4), 1150 -1157. http://dx.doi.org/10.1590/S0100-29452009000400032

Mason, P. E.; Darvell, L. I.; Jones, J. M.; Williams, A. (2016). Observations on the release of gas-phase potassium during the combustion of single particles of biomass. Fuel, 182, 110-117. https://doi.org/10.1016/j.fuel.2016.05.077

Mckendry, P. (2002). Energy production from biomass (part 1): overview of biomass. Bioresource Technology, 83, $37-$ 46. https://doi.org/10.1016/S0960-8524(01)00118-3

Medeiros, C. M. (2016). Caracterização físico-química de resíduos sólidos da indústria de celulose e papel para fins energéticos. Dissertação (Mestrado em Materiais Aplicados às Energias Renováveis) - Universidade Federal da Paraíba, João Pessoa.

Mlonka-Medrala A.; Magdziarz, A.; Gajek, M.; Nowinska, K.; Nowak, W. (2020). Alkali metals association in biomass and their impact on ash melting behavior. Fuel, 261, 1-17. https://doi.org/10.1016/j.fuel.2019.116421

Muniz, R. N. and Rocha, b. R. P. (2013). Gaseificação de biomassa residuária na Amazônia: estudo de caso em comunidade quilombola no Pará. In: $8^{\circ}$ Congresso Internacional de Bioenergia, São Paulo.

Musellim, E.; tahir, M. H.; Ahmad, M. S.; Ceylan, S. (2018). Thermokinetic and tg/dsc-ftir study of pea waste biomass pyrolysis. Applied Thermal Engineering, 137, 54-61. https://doi.org/10.1016/j.applthermaleng.2018.03.050

Oliveira, D. N. P. S.; Claro, P. I. C.; Freitas, R. R.; Martins, M. A.; Souza, T. M.; Silva, B. M. S.; Mendes, L. M.; bufalino, L. (2019). Enhancement of the amazonian açaí waste fibers through variations of alcali pretreatment parameters. Chemistry and Biodiversity, 16, 1-12. https://doi.org/10.1002/cbdv.201900449

Oliveira, M. S. P.; Farias Neto, J. T.; Pena, R. S. (2007). Açaí: técnicas de cultivo e processamento. Fortaleza: Instituto Frutal.

Ong, H. C.; Chen, W.; Singh, Y.; Gan, Y. Y.; Chen, C.; Show, P. L. (2020). A state-of-the-art review on thermochemical conversion of biomass for biofuel production: a TG-FTIR approach. Energy Conversion and Management, 209, 1-21. https://doi.org/10.1016/j.enconman.2020.112634 
Protásio, T. P. (2014). Biomassa residual do coco babaçu: potencial de uso bioenergético nas regiões norte e nordeste do brasil. Dissertação (Mestrado em Ciência e Tecnologia da Madeira) - Universidade Federal de Lavras, Lavras.

Qiao, Y.; Xu, F.; Ming, X.; Feng, S.; Ji, Y.; Jiang, Y.; Li, J.; Wang, b.; Tian, Y. (2020). Valorization of vegetable waste via pyrolysis: thermal behavior, volatiles release and products analysis from its extractives. Energy Fuels, 34, 18961907. https://doi.org/10.1021/acs.energyfuels.9b03970

Queiroz, J. A. L. and Melém Jr., N. J. (2001). Efeito do tamanho do recipiente sobre o desenvolvimento de mudas de açaí (Euterpe oleracea mart.). Revista Brasileira de Fruticultura, 23 (2), 460-462. https://doi.org/10.1590/S0100$\underline{29452001000200054}$

Rambo, M. K. D.; Schmidt, F. L.; Ferreira, M. M. C. (2015). Analysis of the lignocellulosic components of biomass residues for biorefinery opportunities. Talanta, 144, 696-703. https://doi.org/10.1016/j.talanta.2015.06.045

Rangel, R. N. (2014). Modelagem, caracterização e simulação da pirólise do caroço de açaí. Monografia (engenharia de energia) - Universidade de Brasília, Brasília.

Ren, X.; Meng, X.; Vorobiev, N.; Schiemann, M.; Levendis, Y. (2017). Carbon, sulfur and nitrogen oxide emissions from combustion of pulverized raw and torrefied biomass. Fuel, 188, 310-323. https://doi.org/10.1016/j.fuel.2016.10.017

Saidur, R.; Abdelaziz, E. A.; Demirbas, A.; Hossain, M. S.; Mekhilef, S. (2011). A review on biomass as a fuel for boilers. Renewable and Sustainable Energy Reviews, 15, 2262-2289. https://doi.org/10.1016/j.rser.2011.02.015

San Miguel, G.; Domínguez, M. P.; Hernández, M.; Sanz-Pérez, F. (2012). Characterization and potential applications of solid particles produced at a biomass gasification plant. Biomass and Bioenergy, 47, 134-144. https://doi.org/10.1016/j.biombioe.2012.09.049

Santos, R. E. J. (2011). Estudo experimental de um reator de gaseificação em um leito fixo de açaí. Dissertação (Mestrado em Engenharia Mecânica) - Universidade Federal do Pará, Belém.

Sasmal, S.; Goud, V. V.; Mohanty, K. (2012). Characterization of biomasses available in the region of North-east India for production of biofuels. Biomass and Bioenergy, 45, 212-220. https://doi.org/10.1016/j.biombioe.2012.06.008

Silva, A. V. S.; Torquato, L. D. M.; Cruz, G. (2019). Potential application of fish scales as feedstock in thermochemical processes for the clean energy generation. Waste Management, 100, 91-100. https://doi.org/10.1016/j.wasman.2019.09.007

Silva, J. B. S.; Torquato, L. D. M.; Crnkovic, P. M.; Cruz, G. (2021). Investigation of urban pruning wastes as biofuels and possible utilization in thermal systems. Brazilian Journal of Development, 7, 24730-24750. https://doi.org/10.34117/bjdv7n3-265

Sousa, A. C. and Vieira, P. J. C. (2014). Estudo experimental da gaseificação do caroço de açaí. Trabalho de conclusão de curso (Graduação em Engenharia de Energia) - Universidade de Brasília, Brasília.

Souto, B. A.; Souza, V. L. C.; Perazzini, M. T. B.; Perazzini, H. (2021). Valorization of açai bio-residue as biomass for bioenergy: determination of effective thermal conductivity by experimental approach, empirical correlations and artificial neural networks. Journal of Cleaner Production, 279, 1-12. https://doi.org/10.1016/j.jclepro.2020.123484

Souza, N. P.; Rezende Neto, P. C.; Brasileiro, B. C.; Kuhl, R. M.; Muniz, R. N.; Sá, J. A. S.; Rocha, B. R. P. (2015). Electricity generation from residual biomass: project plant gasification jenipaúba, abaetetuba, pa. In: xi latin-american congress on eletricity generation and transmission bioenergy for eletricity generation and ecological issues in power plants, São José dos Campos. Book of Abstracts and Proceedings of 11th Latin-American Congress on Electricity Generation and Transmission - Clagtee. https://doi.org/10.13140/RG.2.1.2529.4168

Torquato, L. D. M.; Crnkovic, P. M.; Ribeiro, C. A.; Crespi, M. S. (2017). New approach for proximate analysis by thermogravimetry using co2 atmosphere: validation and application to different biomasses. Journal of Thermal Analysis and Calorimetry, 128, 1-14. http://doi.org/10.1007/s10973-016-5882-z

Virmond, E.; Sena, R. F.; Albrecht, W.; Althoff, C. A.; Moreira, R. F. P. M.; José, H. J. (2012). Characterisation of agroindustrial solid residues as biofuels and potential application in thermochemical processes. Waste Management, 32 , 1952-1961. https://doi.org/10.1016/j.wasman.2012.05.014 
Vital, A. A. B.; Borba, J. E. M.; Carvalho M. (2018). Geração de energia elétrica num condomínio residencial a partir da gaseificação de biomassa. In: Silva, R. C. P.; Santos, J. P. O.; Mello, D. P.; El-Deir, S. G. (orgs.). Resíduos sólidos: tecnologias e boas práticas de economia circular. $1^{\text {a }}$ ed. Recife: EDUFRPE, 259-270.

Wang, S.; Dai, G.; Yang, H.; Luo, Z. (2017). Lignocellulosic biomass pyrolysis mechanism: a state-of-the-art review. Progress in Energy and Combustion Science, 62, 33-86. https://doi.org/10.1016/j.pecs.2017.05.004

Williams, A.; Jones, J. M.; Ma, 1.; Pourkashanian, M. (2012). Pollutants from the combustion of solid biomass fuels. Progress in Energy and Combustion Science, 38, 113-137. https://doi.org/10.1016/j.pecs.2011.10.001

Yang, Y. B.; Ryu, C.; Khor, A.; Yates, N. E.; Sharifi, V. N.; Swithenbank, J. (2005). Effect of fuel properties on biomass combustion. Part II. Modelling approach - identification of the controlling factors. Fuel. 84, $2116-2130$. https://doi.org/10.1016/j.fuel.2005.04.023 
DECLARATION OF CONTRIBUTIONS TO THE ARTICLE - CRediT

\begin{tabular}{|c|c|c|c|c|c|c|}
\hline ROLE & LOliveira & ASilva & CConconi & EGomes & WBizzo & GCruz \\
\hline $\begin{array}{l}\text { Conceptualization - Ideas; formulation or evolution of overarching } \\
\text { research goals and aims. }\end{array}$ & $\mathrm{X}$ & & & & & $\mathrm{X}$ \\
\hline $\begin{array}{l}\text { Data curation - Management activities to annotate (produce metadata), } \\
\text { scrub data and maintain research data (including software code, where } \\
\text { it is necessary for interpreting the data itself) for initial use and later re- } \\
\text { use. }\end{array}$ & $\mathrm{X}$ & & & & & $\mathrm{X}$ \\
\hline $\begin{array}{l}\text { Formal analysis }- \text { Application of statistical, mathematical, } \\
\text { computational, or other formal techniques to analyze or synthesize } \\
\text { study data. }\end{array}$ & $\mathrm{X}$ & $\mathrm{X}$ & & & & $\mathrm{X}$ \\
\hline $\begin{array}{l}\text { Funding acquisition - Acquisition of the financial support for the } \\
\text { project leading to this publication. }\end{array}$ & & & & & & $\mathrm{X}$ \\
\hline $\begin{array}{l}\text { Investigation - Conducting a research and investigation process, } \\
\text { specifically performing the experiments, or data/evidence collection. }\end{array}$ & $\mathrm{X}$ & & & & & $\mathrm{X}$ \\
\hline $\begin{array}{l}\text { Methodology - Development or design of methodology; creation of } \\
\text { models. }\end{array}$ & $\mathrm{X}$ & & $\mathrm{X}$ & $\mathrm{X}$ & $\mathrm{X}$ & $\mathrm{X}$ \\
\hline $\begin{array}{l}\text { Project administration - Management and coordination responsibility } \\
\text { for the research activity planning and execution. }\end{array}$ & & & & & & $\mathrm{X}$ \\
\hline $\begin{array}{l}\text { Resources - Provision of study materials, reagents, materials, patients, } \\
\text { laboratory samples, animals, instrumentation, computing resources, or } \\
\text { other analysis tools. }\end{array}$ & & & $\mathrm{X}$ & $\mathrm{X}$ & $\mathrm{X}$ & $\mathrm{X}$ \\
\hline $\begin{array}{l}\text { Software - Programming, software development; designing computer } \\
\text { programs; implementation of the computer code and supporting } \\
\text { algorithms; testing of existing code components. }\end{array}$ & & & & & & \\
\hline $\begin{array}{l}\text { Supervision - Oversight and leadership responsibility for the research } \\
\text { activity planning and execution, including mentorship external to the } \\
\text { core team. }\end{array}$ & & $\mathrm{X}$ & & & & $\mathrm{X}$ \\
\hline $\begin{array}{l}\text { Validation - Verification, whether as a part of the activity or separate, } \\
\text { of the overall replication/reproducibility of results/experiments and } \\
\text { other research outputs. }\end{array}$ & $\mathrm{X}$ & & & & & $\mathrm{X}$ \\
\hline $\begin{array}{l}\text { Visualization - Preparation, creation and/or presentation of the } \\
\text { published work, specifically visualization/data presentation. }\end{array}$ & $\mathrm{X}$ & $\mathrm{X}$ & & & & $\mathrm{X}$ \\
\hline $\begin{array}{l}\text { Writing - original draft - Preparation, creation and/or presentation of } \\
\text { the published work, specifically writing the initial draft (including } \\
\text { substantive translation). }\end{array}$ & $\mathrm{X}$ & $\mathrm{X}$ & & & & $\mathrm{X}$ \\
\hline $\begin{array}{l}\text { Writing - review \& editing - Preparation, creation and/or presentation } \\
\text { of the published work by those from the original research group, } \\
\text { specifically critical review, commentary or revision - including pre- or } \\
\text { post-publication stages. }\end{array}$ & $\mathrm{X}$ & $\mathrm{X}$ & $\mathrm{X}$ & $\mathrm{X}$ & $\mathrm{X}$ & $X$ \\
\hline
\end{tabular}

